\title{
Cocconeis molesta Kütz., $C$. diaphana W.Sm. and $C$. dirupta W.Greg. (Bacillariophyta): type material, ambiguities and possible synonymies
}

\author{
Catherine RIAUX-GOBIN ${ }^{1,2, *}$, Pierre COMPÈRE ${ }^{3}$, Richard W. JORDAN ${ }^{4}$, \\ Michel $\operatorname{COSTE}^{5} \&$ Jovita C. YESILYURT ${ }^{6}$ \\ ${ }^{1}$ CRIOBE-USR 3278 CNRS-EPHE-UPVD, 66000 Perpignan, France. \\ ${ }^{2}$ Laboratoire d'Excellence 'CORAIL', 66000 Perpignan, France. \\ ${ }^{3}$ Deceased 29 April 2016. Former address: Botanic Garden Meise, \\ Domein van Bouchout, 1860 Meise, Belgium. \\ ${ }^{4}$ Department of Earth \& Environmental Sciences, Yamagata University, Yamagata 990-8560, Japan. \\ ${ }^{5}$ IRSTEA, 50 avenue de Verdun, Cestas, France. \\ ${ }^{6}$ The Natural History Museum, Department of Life Sciences, Cromwell Rd, \\ SW7 5BD, London, United Kingdom. \\ * catherine.gobin@univ-perp.fr (corresponding author) \\ ${ }^{4}$ sh081@kdw.kj.yamagata-u.ac.jp \\ ${ }^{5}$ michel.coste@irstea.fr \\ ${ }^{6}$ j.yesilyurt@nhm.ac.uk
}

\begin{abstract}
F.T. Kützing introduced Cocconeis molesta with only an uninformative description and a poor illustration: C. molesta has small, oblong valves and is an epiphyte. Another species, Cocconeis diaphana, described by William Smith, is said to have larger valves than C. molesta, with frustules that are relatively oblong. Smith described two forms: one with a distinct fascia on its raphe valve (var. $\beta$ ), the other without this feature. A third species, Cocconeis dirupta was described by Gregory, who expressed doubts that it differed from $C$. diaphana. Finally, Cocconeis molesta var. crucifera Grunow was first introduced in Van Heurck's Atlas but was subsequently treated by Van Heurck as a synonym of $C$. molesta. No previous account has examined the type material of these species. In this paper, we undertake that task and examine type slides and raw material in order to discriminate these different taxa. We conclude by recognizing three species: Cocconeis molesta Kütz., C. diaphana W.Sm. and $C$. dirupta W.Greg. Cocconeis diaphana var. $\beta$ is considered to be a synonym of $C$. dirupta and C. molesta var. crucifera is considered to be a synonym of C. molesta. Lectotypes are designated for C. diaphana and C. dirupta.
\end{abstract}

Keywords. Cocconeis molesta, Cocconeis diaphana, Cocconeis dirupta, synonymies, types.

Riaux-Gobin C., Compère P., Jordan R.W., Coste M. \& Yesilyurt J.C. 2016. Cocconeis molesta Kütz., C. diaphana W.Sm. and C. dirupta W.Greg. (Bacillariophyta): type material, ambiguities and possible synonymies. European Journal of Taxonomy 204: 1-18. http://dx.doi.org/10.5852/ejt.2016.204 


\section{Introduction}

The diatom genus Cocconeis Ehrenb. (Ehrenberg 1837: 173) is diverse, comprising numerous small species, several of which are very similar and difficult to identify. Thus, there is a need to re-examine the type material in order to improve, clarify and expand the original descriptions and to determine whether or not these taxa are synonymous. Unfortunately, most diatom species are identified by comparing specimens collected from places other than the type locality. However, in the case of Cocconeis, studies on the type material have been increasing (Jahn et al. 2009; Romero 2011; Riaux-Gobin et al. 2014a, 2014b; Romero \& Riaux-Gobin 2014), particularly the detailed examination of raw type material with a scanning electron microscope (SEM) (e.g. Romero \& Riaux-Gobin 2014).

Herein, we focus on Cocconeis molesta Kütz., Cocconeis diaphana W.Sm., Cocconeis dirupta W.Greg. and some other taxa pertaining to the same group, all of which are small and very similar in morphological characteristics (under LM), and may have led to taxonomic confusion in the past (see Discussion).

\section{Taxonomic history of Cocconeis molesta Kütz., Cocconeis diaphana W.Sm., Cocconeis dirupta W.Greg. and allied taxa}

Cocconeis molesta Kütz. was introduced along with a poor illustration and very succinct description, which mentioned only the small size and oblong shape of the frustule and that it was epiphytic on Callithamnion cruciatum (C.Agardh) Nägeli (Kützing 1844: 71, pl. 5, fig. 7, reproduced in Fig. 1).

Another species with a relatively oblong frustule but with larger dimensions than C. molesta was subsequently described as Cocconeis diaphana W.Sm. (Smith 1853: 22, pl. 30, fig. 254, reproduced in Figs 2-3), and included two varieties; one without a distinct fascia and the other with a conspicuous fascia $(\beta)$, with the latter accompanied by a laconic note stating " $\beta$. Nodule dilated into a stauros". These forms will be cited hereafter as var. diaphana and var. $\beta$. Two varieties, corresponding more or less to var. diaphana and var. $\beta$, were later described as $C$. diaphana var. amygdalina Grunow ex Cleve (Cleve 1895) without a fascia, and C. diaphana var. dirupta (W.Greg.) Rabenh. (Rabenhorst 1864) with a distinct fascia, respectively.

Cocconeis dirupta W.Greg. was introduced with some doubt about how it differed from C. diaphana (Gregory 1857: 491, pl. 9, fig. 25, reproduced in Fig. 4), with C. dirupta described as brown colored with conspicuous striae, while $C$. diaphana (noted by Gregory as also present in his material, see C. dirupta type material discussion) was diaphanous (cf. Gregory 1857: 491).

Lastly, Cocconeis molesta var. crucifera Grunow ex Cleve was invalidly described in Van Heurck (1880-1885: pl. 30, figs 20-23, reproduced in Figs 5-8) and afterwards classified as a synonym of C. molesta by Van Heurck (1896: 291, pl. 29, fig. 823). Van Heurck (1896) examined C. molesta type material, from the isotype present in his collection (Kützing 259) and noticed the stauros on the raphe valve and produced drawings identical to those first illustrated as C. molesta var crucifera in Van Heurck (1880-1885: pl. 30, figs 22-23).

Most of the above cited taxa (see further comments below), have been described with a fascia (or stauros), particularly on their raphe valve, and have poor original descriptions. Although several studies have contributed to a better understanding of these taxa, unresolved problems still remain, while other studies have provided revised descriptions that did not include observations on the types (e.g. about C. dirupta: Hustedt 1931-1959; Foged 1978; Kobayasi \& Nagumo 1985; Sar et al. 2003; Riaux-Gobin et al. 2011; Lobban et al. 2012; about C. diaphana: Álvarez-Blanco \& Blanco 2014; about C. molesta var. crucifera: De Stefano et al. 2000; Sar et al. 2003). 
We here examine several original materials that were cited in the protologues in order to discriminate different taxa, clarify their definitions and resolve their nomenclatural issues, including synonymies, confirmation of types and designation of a lectotype for Cocconeis diaphana.

\section{Material and methods}

Materials used in this study derived from several sources:

(1) Friedrich Traugott Kützing collection, no. 259, type material of Cocconeis molesta Kütz., from Venedig, collector F.T. Kützing; herbarium specimen (BM 000905975) with raw material in mica; slide (BM 18381 made from the same 259 material) in collection, both housed in the Natural History Museum, London (BM). This material is type material. Fig. 9.

(2) Henri Ferdinand Van Heurck collection, slide IX-43-A13 labelled Cocconeis molesta Kg Méditerranée Kützing no. 259, probably mounted by H. Van Heurck from the collection no. 259 of Kützing, collected on Callithamnium cruciatum, housed in the Van Heurck collection, Botanic Garden Meise (BR). The slide BM 18381 (see above) was also made using the Kützing type material (no. 259); Van Heurck's slide is an isotype. Fig. 10.

(3) William Smith collection, no collection number (mounted in 1887, unknown mounter), Pontac, Jersey, Aug. 1852, type material of Cocconeis diaphana W.Sm.: slides BM 23161 (Fig. 11) and BM 23162, all housed in BM.

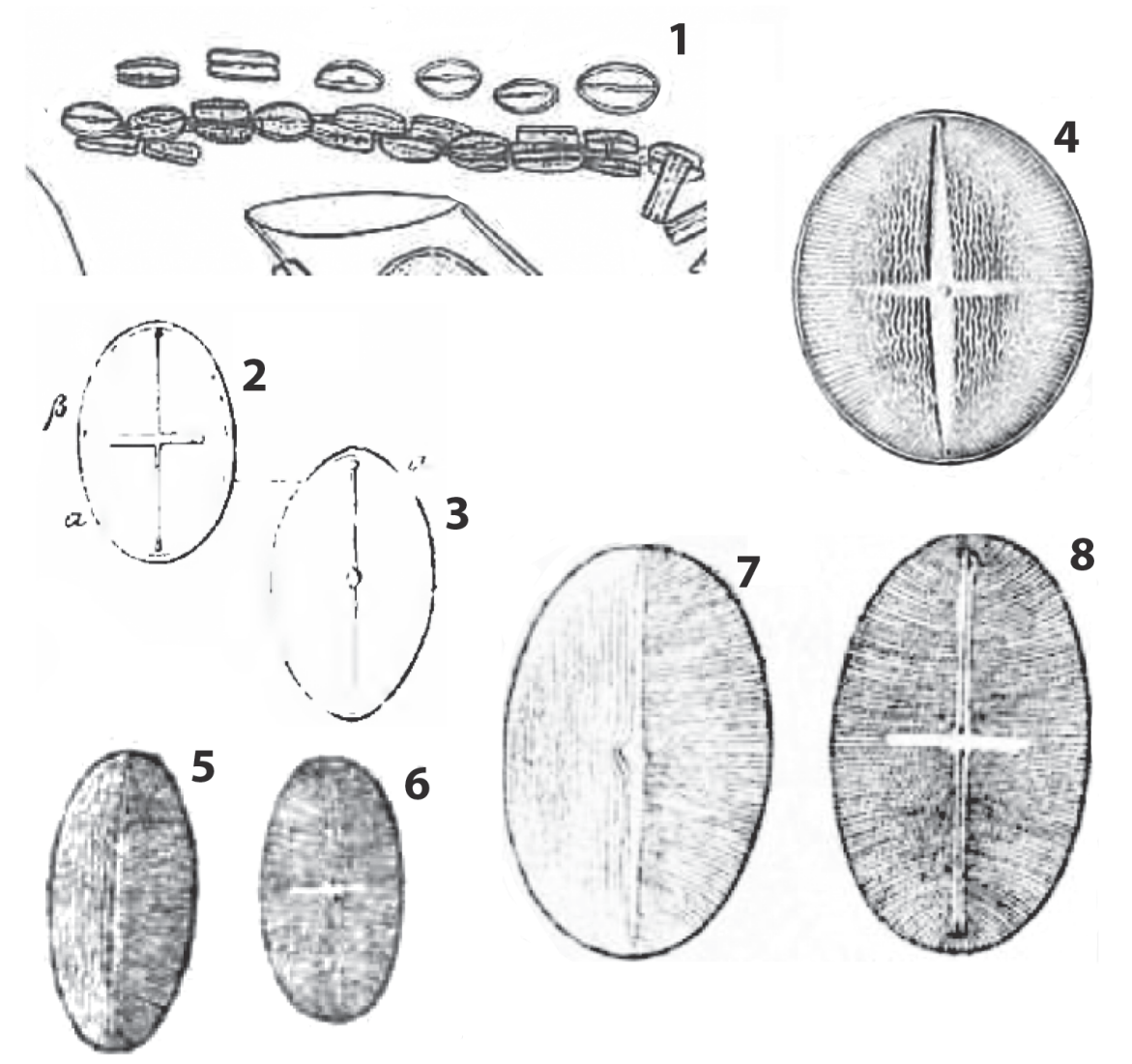

Figs 1-8. Original drawings. 1. Cocconeis molesta Kütz. (Kützing 1844, pl. 5, fig. 7). 2-3. Cocconeis diaphana W.Sm. (Smith 1853, pl. 30): 2. var. $\beta$. 3. type C. diaphana var. diaphana. 4. Cocconeis dirupta W.Greg. (Gregory 1857, pl. 9). 5-8. Cocconeis molesta var. crucifera Grunow ex Cleve (Van Heurck 1880-1885, pl. 30): 5-6. f. minor. 7-8. f. major. 
(4) Freeman Clarke Samuel Roper collection, no. 1212, material of Cocconeis diaphana W.Sm. (with an almost illegible round red label), Sidmouth (the inscription "WS 254" written by diamond pen in reference to fig. 254 of the W. Smith Synopsis). Collector W. Smith, slide BM 19589 housed in BM. Fig. 12. This material is assumed to be a syntype.

(5) Henri Ferdinand Van Heurck collection, no. VI-45-B10 (housed in BR, Fig. 13), W. Smith material mounted by W. Smith's nephew, Charles Coppock. Determined by W. Smith as Diatomaceae, Cocconeis diaphana (written on a round red label). The inscription "WS 254" (see above) was written by diamond pen on the slide: $\beta$, Sidmouth, along with the mention. Collector "Miss Cutler, communicated by Dr Greville" (Catherine Cutler of Sidmouth (1784-1866) was a distinguished algologist). This slide is considered to be an isosyntype.

(6) Robert Kaye Greville collection, material of Cocconeis dirupta W.Greg., from Arran 56: slide BM 1420, Fig. 14 (no diamond ringed specimens). Type specimens were neither indicated by W. Gregory or R.K. Greville since this was not required at that time; a curator of BM (see label on the left side of the cover slip; specimen probably identified by Robert Ross) assumed this to be an isotype of Cocconeis dirupta; in fact this is a syntype.

The diatoms on the permanent slides were observed with (1) an Olympus BX51 microscope, equipped with a colorview camera (National Botanic Garden, Meise, Belgique) and (2) a Zeiss Axiophot 200 microscope with differential interference contrast (DIC, obj. $100 \times 2.5$ ) and photographed with a Canon PowerShot EOS1000D digital camera (CRIOBE, Perpignan, France). A comparison of morphological features and biometric data of the type slide taxa are provided in Table 1.

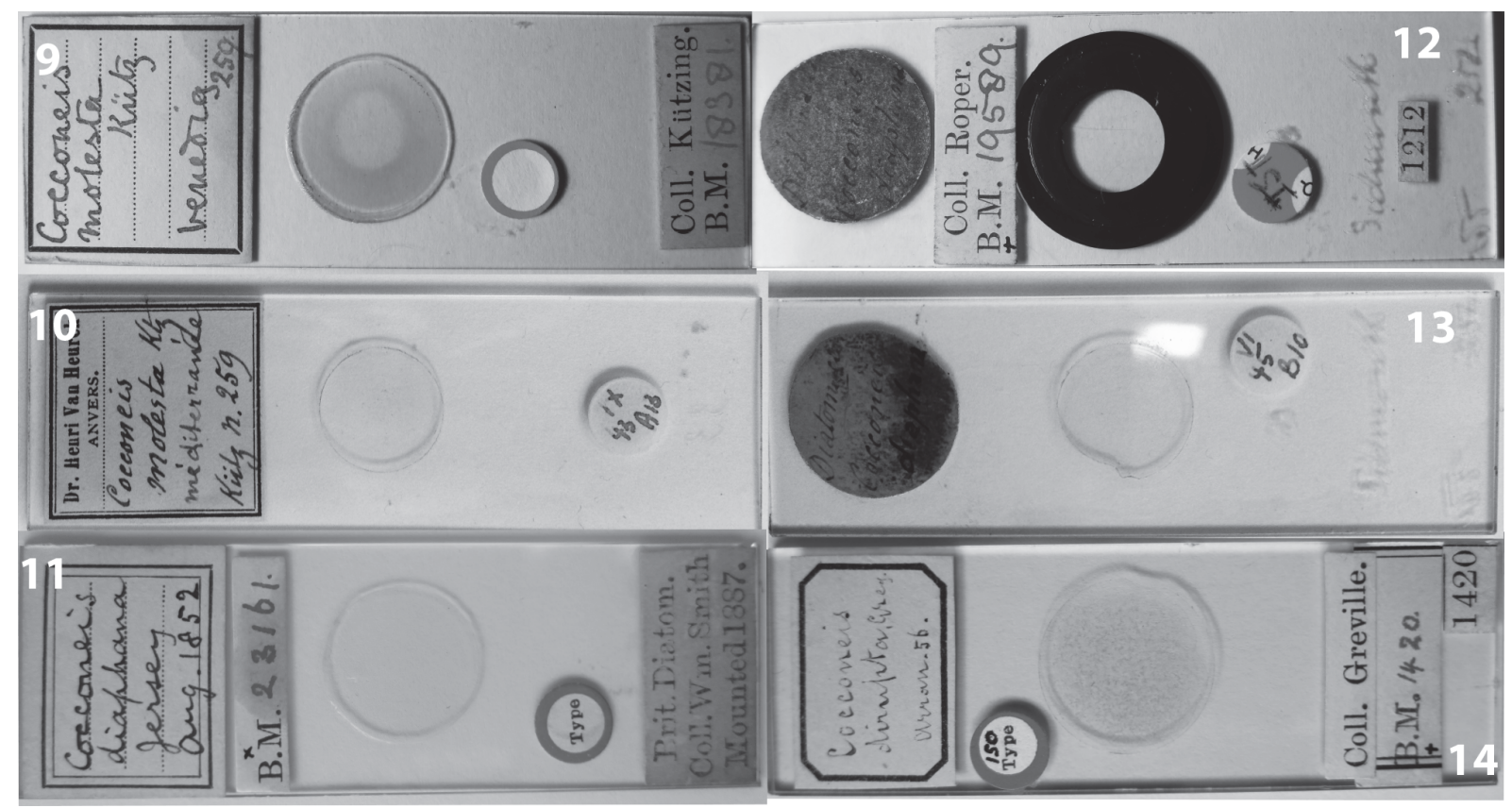

Figs 9-14. Illustration of the type slides. 9. Cocconeis molesta Kütz.: F.T. Kützing collection, no. 259, BM 18381. 10. Cocconeis molesta: H.F. Van Heurck collection, no. IX-43-A13. 11. Cocconeis diaphana W.Sm.: W. Smith collection, "Jersey, Pontac" August 1852, BM 23161. 12. Cocconeis diaphana: F.C.S. Roper collection, "Sidmouth", no. 1212, BM 19589. 13. Cocconeis diaphana: H.F. Van Heurck collection, "Sidmouth", no. VI 45B10. 14. Cocconeis dirupta W.Greg.: R.K. Greville collection, Arran 56, BM 1420. 


\begin{tabular}{|c|c|c|c|c|c|c|c|c|c|c|c|}
\hline 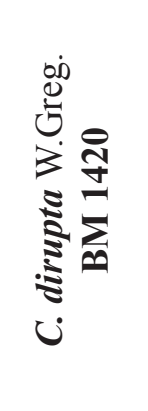 & 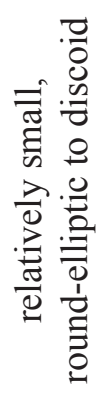 & $\begin{array}{l}n \\
\tilde{b} \\
\tilde{n} \\
n \\
\infty \\
\infty\end{array}$ & $\begin{array}{l}\infty \\
\dot{0} \\
\text { } \\
\stackrel{1}{~} \\
\stackrel{1}{I}\end{array}$ & $\begin{array}{l}\sim \\
+1 \\
b \\
0 \\
0\end{array}$ & 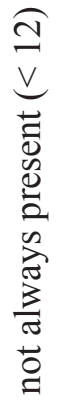 & $\begin{array}{l}\vec{H} \\
\hat{\sigma} \\
\infty\end{array}$ & 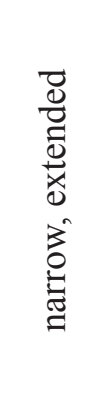 & $\stackrel{\nearrow}{\leftrightarrows}$ & 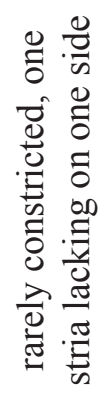 & $\begin{array}{l}\vec{w} \\
\overrightarrow{0} \\
0 \\
0 \\
0 \\
0 \\
0 \\
0 \\
0\end{array}$ & 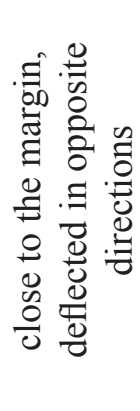 \\
\hline 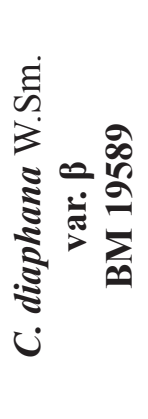 & 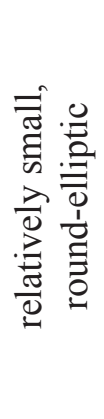 & $\begin{array}{l}\stackrel{1}{1} \\
\stackrel{2}{\sigma}\end{array}$ & ָे & $\begin{array}{l}\stackrel{\nabla}{-} \\
\dot{H} \\
\stackrel{\lambda}{ }\end{array}$ & 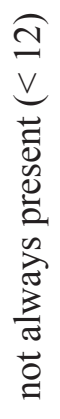 & $\begin{array}{l}n \\
0 \\
+1 \\
\tilde{N}\end{array}$ & 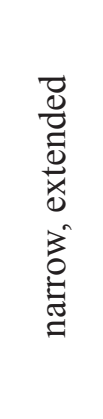 & $\stackrel{?}{\rightleftarrows}$ & 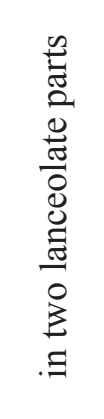 & $\begin{array}{l}\vec{y} \\
\overrightarrow{0} \\
0 \\
0 \\
0 \\
0 \\
0 \\
0 \\
0\end{array}$ & 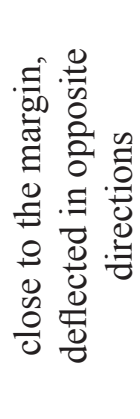 \\
\hline 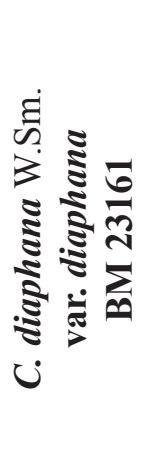 & 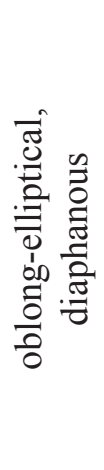 & $\begin{array}{l}\text { f } \\
\text { m }\end{array}$ & $\stackrel{\stackrel{0}{\sim}}{\stackrel{N}{N}}$ & $\begin{array}{l}\text { Na } \\
\text { N } \\
+1 \\
\stackrel{\sim}{N}\end{array}$ & $\tilde{\sim}$ & $\begin{array}{l}\hat{0} \\
+1 \\
\tilde{N}\end{array}$ & 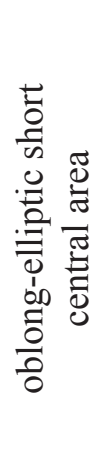 & $\underset{n}{n}$ & 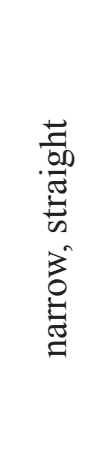 & $\begin{array}{l}0 \\
\frac{0}{0} \\
\end{array}$ & 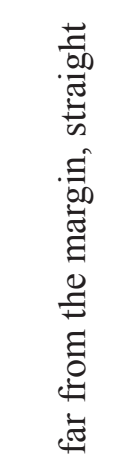 \\
\hline 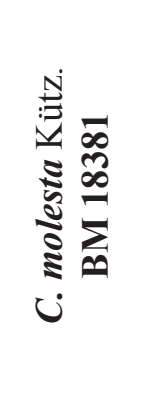 & 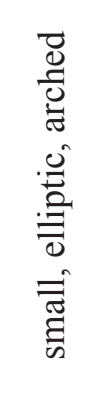 & $\stackrel{\nabla}{\circ}$ & $\hat{a}$ & 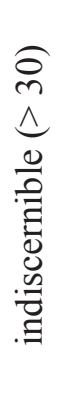 & $\begin{array}{l}\stackrel{\text { }}{\sim} \\
\stackrel{\sim}{\sim}\end{array}$ & 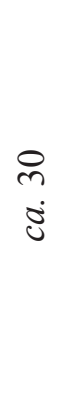 & 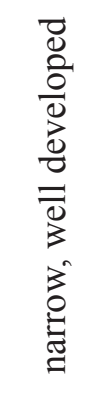 & $\stackrel{\text { gి }}{.}$ & 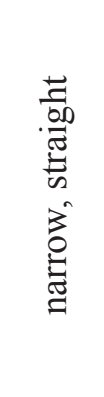 & $\begin{array}{l}\vec{w} \\
0 \\
0 \\
0 \\
0 \\
0 \\
0 \\
0\end{array}$ & 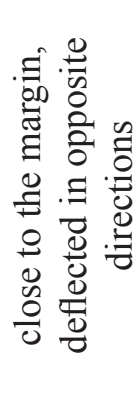 \\
\hline 莺 & $\begin{array}{l}\frac{\partial}{\pi} \\
\frac{\pi}{\pi} \\
\frac{D}{\pi} \\
\frac{D}{\pi}\end{array}$ & 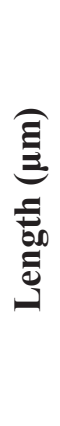 & 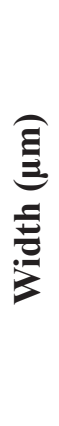 & 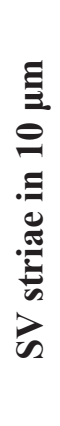 & 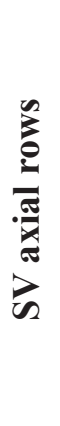 & 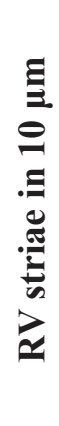 & 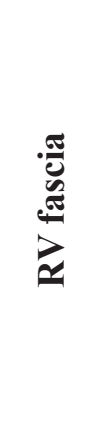 & 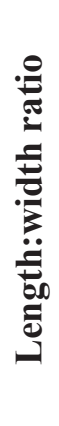 & 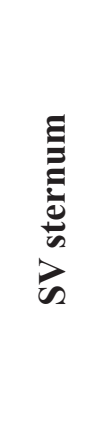 & 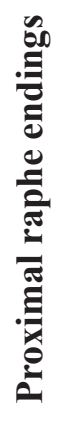 & 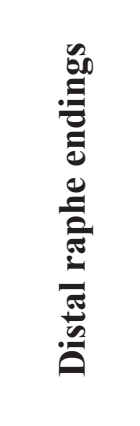 \\
\hline
\end{tabular}




\section{Terminology and abbreviations}

For the description of the frustule, terminology follows Anonymous (1975), Ross et al. (1979) and Round et al. (1990). As previously proposed, in particular by Riaux-Gobin et al. (2013), we designate the valve with a raphe as the raphe valve (RV) and the valve without a raphe as the sternum valve (SV).

Since some of the original raw material used by F.T. Kützing has been found, whereas the same was not possible for W. Smith, R.K. Greville and W. Gregory, scanning electron microscope (SEM) observations have been made on only one type material. Nevertheless, modern light microscopy allows the striation and other valve features to be observed on the type slides, so that the original description can be emended.

\section{Results}

Class Bacillariophyceae Haeckel emend. Medlin \& Kaczmarska (Medlin \& Kaczmarska 2004)

Subclass Bacillariophycidae D.G.Mann in Round et al. (Round et al. 1990)

Family Cocconeidaceae Kütz. (Kützing 1844)

Cocconeis molesta Kütz. (Kützing 1844)

Figs 1, 15-20, Table 1

Cocconeis molesta var. crucifera Grunow ex Cleve (1895: 174). Type: pl. 30, fig. 23 in Van Heurck (1880-1885).

\section{Original description}

Kützing (1844): 71, pl. 5, fig. 7. 1-2, reproduced in Fig. 1

"C. minuta, elliptico-oblonga, densissime aggregata, laevissima; limbo nullo. An Callithamnion cruciatum in den Lagunen von Venedig ! (Laguna Veneta, Italy) - Länge 1/150-1/140". - "fig. 1. geglüheten Exemplare, fig. 2. aufgeweichte Exemplare".

\section{Emended description by Van Heurck}

Van Heurck (1896: 290, pl. 29, fig. 823) after observation of the original specimen (F.T. Kützing no. 259 in Van Heurck collection): "valves small, elliptic, finely striate; transverse striae about 40 in 1 c.d.m., reaching to the raphe, formed of puncta, distant and consequently capable of forming longitudinal lines undulate or decussate (according to the direction of the illumination). Raphe robust; central nodule elongated into a narrow acute stauros. Length, 1.5 to 2 c.d.m. Breadth, 1 c.d.m. Marine. North Sea".

\section{Type material}

“An Callithamnion cruciatum in den Lagunen von Venedig" (Kützing 1844: 71; Kützing 259, Herbarium sheet BM 000905975, BM 18381, holotype); BR slide IX-43-A13 (Van Heurck collection, Kützing 259, isotype).

\section{Notes}

Van Heurck (1896) after studying material from F.T. Kützing, emended the description and stated that the observed specimen "corresponds to the var. crucifera of Grunow (H.V.H. Atl.: pl. 20, fig. 20)" (Van Heurck 1880-1885: pl. 30, fig. 20) and added "it appears to me right to consider it as the type form".

\section{LM examination of the type material and completed description}

Cf. Riaux-Gobin \& Compère (2008): figs 56-57; Figs 15-17 from BM 18381, Figs 18-20 from slide IX-43-A13. 
The frustule is small ( $c a$. $16.4 \mu \mathrm{m}$ long, $9.7 \mu \mathrm{m}$ wide) and strongly arched (RV concave, SV convex). The RV striation is hardly discernible, with $c a .30$ striae in $10 \mu \mathrm{m}$ (Fig. 18, arrowhead). The SV areolae are arranged along axial rows in a zig-zag pattern $(22-23$ rows in $10 \mu \mathrm{m}$, Figs $16,17,20)$. The helictoglossae are close to the margin and deflected in opposite directions (Fig. 15), the raphe is straight. The SV sternum is narrow and straight, with a small oblong central area. The RV fascia is narrow and half a valve in length.

\section{SEM examination of the Herbarium sheet BM 000905975}

The material is very poor and only a broken SV of Cocconeis molesta was observed, with the following morphometrics and features: estimated valve length $(>17 \mu \mathrm{m})$, SV stria density (40-42 in $10 \mu \mathrm{m}$,

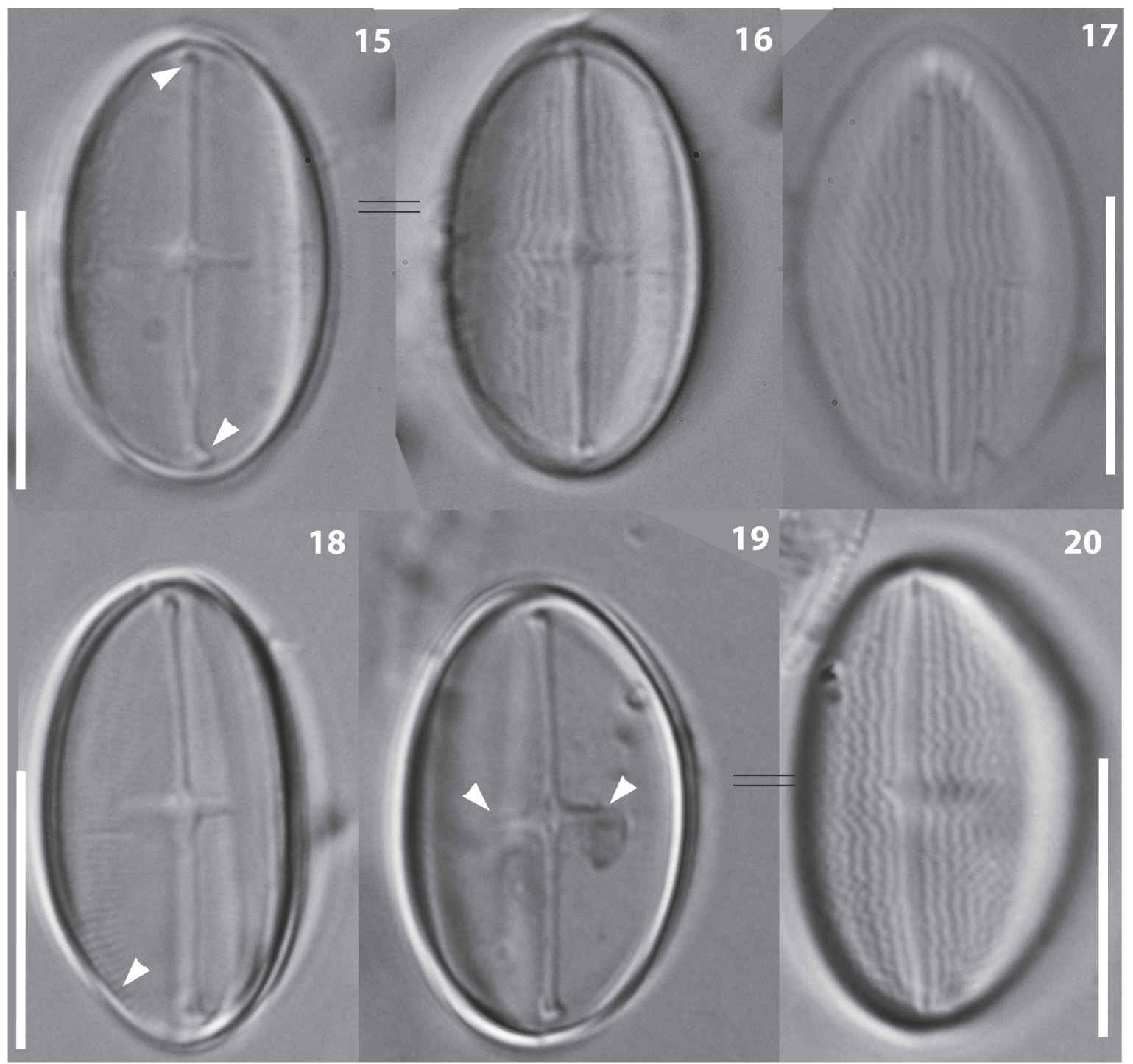

Figs 15-20. Cocconeis molesta Kütz. 15-17. From BM 18381 (15-16: holotype illustration); helictoglossae deflected in opposite directions (15, arrowheads), SV axial rows in a zig-zag pattern (16-17). 18-20. From IX-43-A13 (H.F. Van Heurck collection), RV striation often difficult to observe (18, arrowhead), RV fascia (19, arrowheads), SV axial rows in a zig-zag pattern (20). Scale bars = $10 \mu \mathrm{m}$. 
areolae small and transversely oblong), apical SV row of areolae, in a zig-zag pattern (27.5 in $10 \mu \mathrm{m})$, SV sternum narrow and thickened in internal view, central area slightly enlarged.

Cocconeis diaphana W.Sm. (Smith 1853)

Figs 2-3, 21-34, Table 1

Cocconeis molesta var. amygdalina Grunow ex Cleve (1895: 174).

Cocconeis amygdalina Bréb. ex Grunow in Van Heurck (1880-1885: pl. 30, figs 22-23), nom. inval.

\section{Original description}

Smith (1853): 22, pl. 30, fig. 254, reproduced in Figs 2-3.

"Cocconeis diaphana, n. sp. V. elliptical, scarcely siliceous, diaphanous; striae obscure. Length .0012" to .0018 " (30.48 to $45.72 \mu \mathrm{m})$. v.v. $\beta$ Nodule dilated into a Stauros. Marine. Sidmouth, Miss Cutler, communicated by Dr. Greville. Pontac, Jersey, Aug. 8, 1852, W. Sm. Supp. Plate XXX. 254”.

\section{Type material}

"Marine. Sidmouth, Miss Cutler..." "Pontac, Jersey... W. Sm.”, syntypes; "Pontac, Jersey... W. Sm.", BM 23161, here designated as lectotype; BM 23162, isolectotype; The other syntype, BM 19589, from Sidmouth, belongs to C. dirupta Gregory.

\section{Notes}

When W. Smith introduced $C$. diaphana, he also proposed an unnamed variety $\beta$ characterized by "the nodule dilated into a stauros". This variety, mostly represented in the Sidmouth gathering, though originally a syntype must be excluded from this species. It will be here treated as belonging to C. dirupta W.Greg. (see further comments under this species). The original drawings of $C$. diaphana (Smith 1853, fig. 254) show relatively oblong valves, one without any stauros, the other, marked $\beta$, with a distinct stauros on the RV.

Van Heurck (1896: pl. 29, fig. 823bis) reports Cocconeis molesta var. amygdalina as a "synonym of C. diaphana W.Sm. partim, S.B.D., i., p. 22, pl. 30, fig. 254; H.V.H. Atl., pl. 30, figs 5 and 35", and comments that it is: "much larger in size, 3.5 to 4.5 c.d.m. (35 to $45 \mu \mathrm{m})$. Central nodule rounded, surrounded by small hyaline area. Marine [...] Jersey (W.Sm.)".

\section{Description of specimens from "Jersey, Pontac", after LM examination of the type material}

BM 23161 (Figs 21-26) contains oblong-elliptical, thinly silicified and diaphanous valves, 33-42 $\mu \mathrm{m}$ $(38 \mu \mathrm{m} \pm 2.5 \sigma)$ long, $21-26(23 \mu \mathrm{m} \pm 2.2)$ wide, $1 / \mathrm{L} 1.65 \pm 0.2$, with $26 \pm 2.2 \mathrm{SV}$ striae in $10 \mu \mathrm{m}$, $25 \pm 0.7 \mathrm{RV}$ striae in $10 \mu \mathrm{m}$, and ca. 23 axial SV rows in a zig-zag pattern (Fig. 26). The SV sternum is straight and narrow, the central area very reduced (Figs 23-24). The RV has clearly identifiable striae, with 25 areolae in $10 \mu \mathrm{m}$. The RV fascia is short and quite high, with the aspect of an elliptic central area more than a real fascia. The helictoglossae are straight and off the margin (Fig. 24). As this slide (BM 23161) contains the specimen best matching the original description, we here designate it as the lectotype of C. diaphana W.Sm.

\section{Remark}

Thanks to the kindness of Bart Van de Vijver we have received several SEM photographs of the isolectotype of Cocconeis diaphana deposited in the Van Heurck collection in Meise (BR). This material is epiphytic on marine Rhodophyceae, and is present on a mica labelled "Cocconeis diaphana n.sp., Jersey, Aug. 14. 1852", preserved in the W. Smith collection, vol. I, p. 33. These SEM photographs (Figs 39-44) are a perfect match for the LM figures in this paper and support our emended description. 


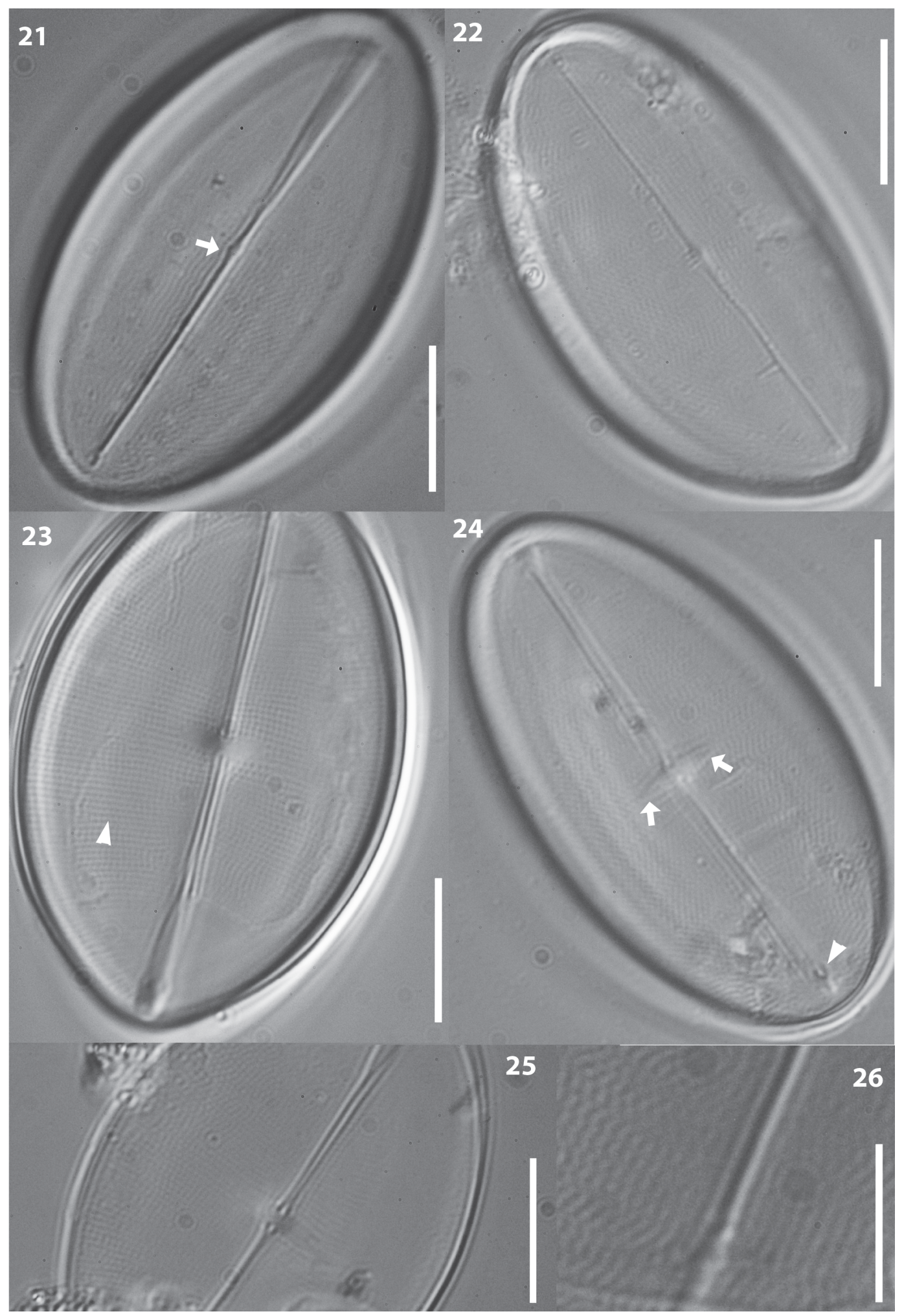

Figs 21-26. Cocconeis diaphana W.Sm. var. diaphana from BM 23161, "Jersey, Pontac". 23. Lectotype illustration. SV sternum narrow and straight (21-22), SV central area small (21, arrow), SV axial rows in a zig-zag pattern $(21-22,26)$. RV striation easily discernible and beaded (23, arrowhead), RV central area transapically enlarged but short (24, arrows), proximal raphe endings robust and close (25). Scale bars $=10 \mu \mathrm{m}(21-25), 5 \mu \mathrm{m}(26)$. 


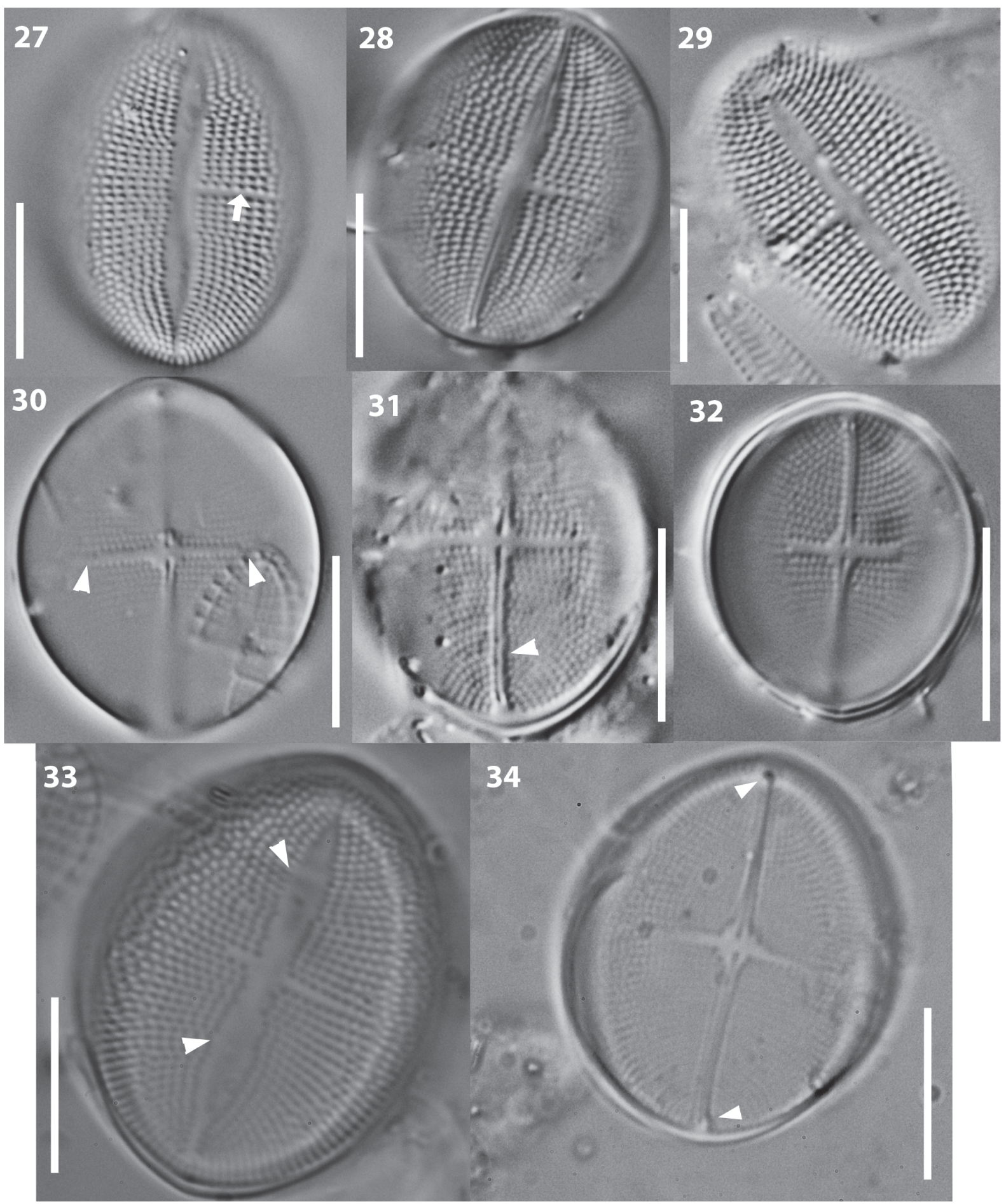

Figs 27-34. Cocconeis diaphana W.Sm. "Sidmouth" (var. $\beta$ ). 27-32. From VI-45-B10 (H.F. Van Heurck collection). One SV stria lacking on one side, or both sides (27, arrow, 28-29), RV fascia narrow and extended (30, arrowheads), raphe slightly sigmoid (31, arrowhead), proximal raphe endings robust (30-32). 33-34. From BM 19589, SV sternum in two lanceolate parts (33, arrowhead), helictoglossae deflected in opposite directions (34, arrowheads). Scale bars $=10 \mu \mathrm{m}$. 


\section{Description of specimens from "Sidmouth", after LM examination of the type material}

The Van Heurck collection (VI-45-B10, Figs 27-32) has specimens that are 15-24 $\mu \mathrm{m}(20.5 \pm 3.2 \sigma)$ long, 14-18.3 $(16 \pm 2.4)$ wide, $1 / \mathrm{L} 1.28 \pm 0.1$, with $18.7 \pm 1.1 \mathrm{SV}$ striae in $10 \mu \mathrm{m}$, and $22.7 \pm 2.2 \mathrm{RV}$ striae in $10 \mu \mathrm{m}$. Slide VI-45-B10 only shows the var. $\beta$.

The W. Smith collection (BM 19589, Figs 33-34) has specimens that are 19-26 $\mu \mathrm{m}(22 \pm 2.9 \sigma)$ long, $16-20(18.6 \pm 2)$ wide, $1 / \mathrm{L} 1.19 \pm 0.05$, with $20 \pm 1.4 \mathrm{SV}$ striae in $10 \mu \mathrm{m}$, and $22 \pm 0.5 \mathrm{RV}$ striae in $10 \mu \mathrm{m}$.

Valves round-elliptical, relatively small. The SV is coarsely striated and punctuated, usually with no axial rows of areolae. The SV sternum is large and composed of two lanceolate parts (Figs 27-29, 33), one median SV stria lacking on one side (Fig. 27, arrow) or both (Fig. 33). The RV has coarsely punctuated striae, strongly radiate. The RV fascia is narrow and wide (often more than half a valve in length). The raphe is often slightly sigmoid with helictoglossae deflected towards opposite sides (Fig. 34). Slide BM 19589 only shows the variety $\beta$.

The two examined slides of "C. diaphana Sidmouth" (VI-45-B10/BR and BM 19589) show valves with similar characteristics (Figs 27-34, 33-34), close to those of Cocconeis dirupta W. Gregory (Figs $35-38$, see below). Therefore, var. $\beta$ is here excluded from $C$. diaphana and considered as a synonym of $C$. dirupta.

\section{Cocconeis dirupta W.Greg. (Gregory 1857)}

Figs 4, 35-38, Table 1

Cocconeis diaphana W.Sm. var. $\beta$ (“Sidmouth material”).

\section{Original description}

Gregory (1857): 491, 492, pl. 9, fig. 25 reproduced in Fig. 4.

"Broad short oval to orbicular. Length 25.4 to $61 \mu \mathrm{m}$; breadth 17.8 to $53.3 \mu \mathrm{m}$ ". "Valve thick. Median line irregular, like a slit. Wavy longitudinal striae, except the slit. Fine transverse striae. Appearance of a long stauros, which, under a higher power, disappears as such. The striated surface seems to be 'torn asunder in the middle'. Vertical striae about 26, transverse striae about 60 in 1 c.d.m.”.

\section{Type material}

Lectotype, designated here: slide BM 1420, labelled "Arran 56" in Greville collection, the only syntype found in BM.

\section{Notes}

Several localities (Glenshira sand, Mr Miles's Corallina gathering and several dredgings) cited by Gregory in the original description could contain syntypes, but only the one designated as lectotype was found in BM. According to W. Gregory " $C$. diaphana $[. .$.$] which was found occurring with C$. dirupta $[\ldots]$ may perhaps be an imperfect form of $C$. dirupta [...] or possibly [...] the lower valve' of the latter", with some further notes that "it is, however equally probable that these forms belong to different species".

\section{LM examination of the type material and completed description}

Figs 35-38, from BM 1420: $\mathrm{n}=16$, valves are 18.3-36.5 (20 \pm 6$) \mu \mathrm{m}$ long, 17.2-30.8 (26.6 \pm 4.7$) \mu \mathrm{m}$ wide; with $13.5-19.5(16.6 \pm 2) \mathrm{SV}$ striae in $10 \mu \mathrm{m}$, and 16-23 $(18.9 \pm 1.9) \mathrm{RV}$ striae in $10 \mu \mathrm{m} . \mathrm{L} / \mathrm{l}$ : $1.12 \pm 0.06$. Valves thick, round-elliptic to almost discoid. Valves rarely found separate, appearing darkbrown. SV with coarse radiate striae, equidistant, composed of transapically oblong areolae arranged in 
a zig-zag pattern along longitudinal lines, areolae smaller near the margin. One median stria often shorter on one side of the central area (Figs 35-36, arrows). Presence of intercalary short striae near the margin. SV sternum relatively large, fusiform (rarely constricted in its mid-part) with apices often deflected in opposite directions (not illustrated). RV with delicate but clearly identifiable striae, equidistant, strongly bent at the apices, with frequent intercalary short striae near the margin. Raphe almost straight to slightly sigmoid (Fig. 37). RV axial area narrow. Distal raphe fissures close to the margin. Helictoglossae often clearly deflected in opposite directions (Fig. 37, arrowheads); presence of a large and narrow transverse fascia (never reaching the margin, formed by one or two shorter striae, Fig. 38, arrows); proximal raphe endings coarse and relatively close.

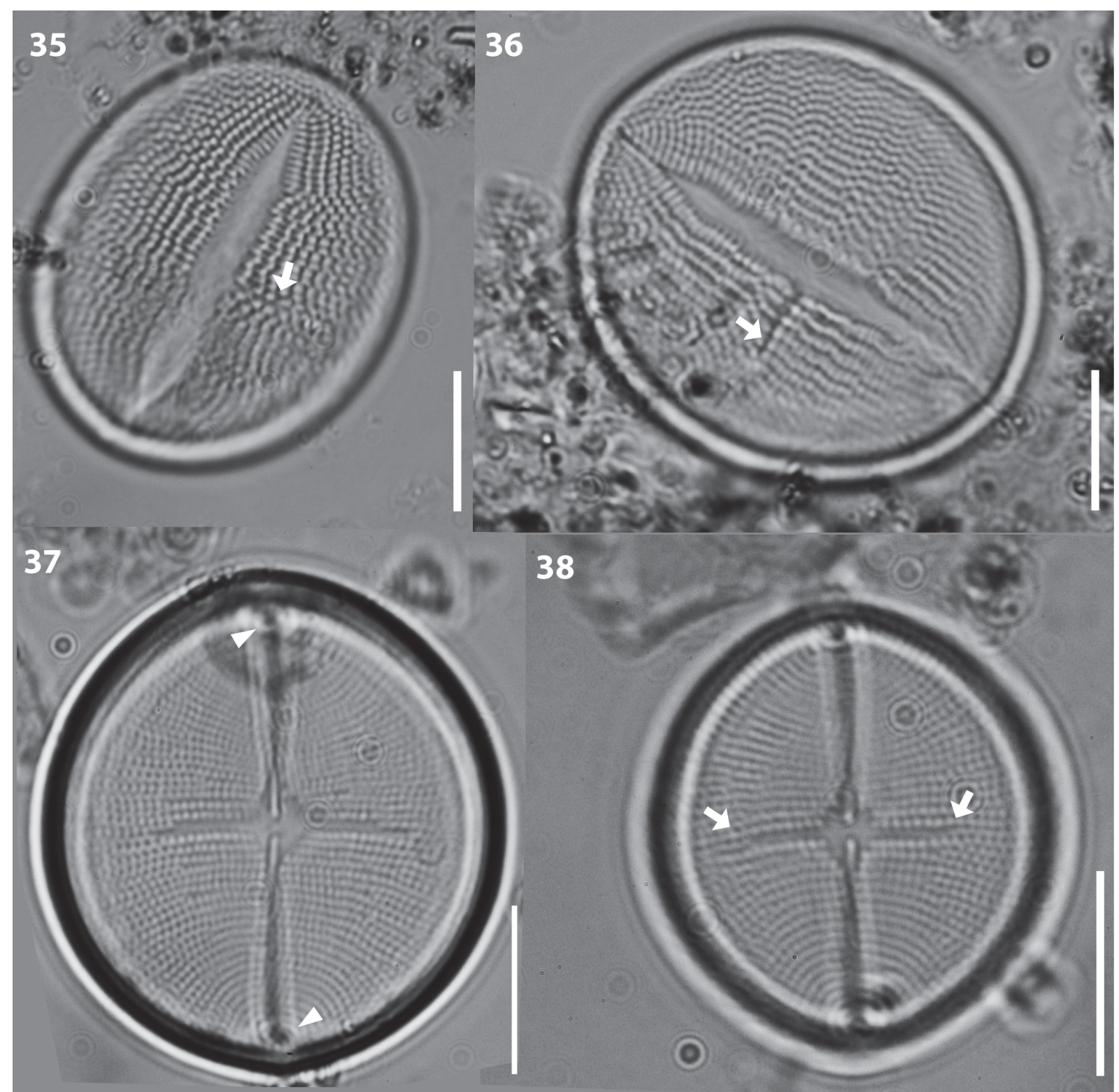

Figs 35-38. Cocconeis dirupta W.Greg. from BM 1420. 37. Lectotype illustration. SV sternum lanceolate with apices slightly bent in opposite directions (36), one SV stria lacking on one side (35, 36, arrow), RV striae strongly radiate, RV fascia narrow and extended (38, arrows), helictoglossae deflected in opposite directions (37, arrowheads) and raphe slightly sigmoid (37). Scale bars $=10 \mu \mathrm{m}$. 


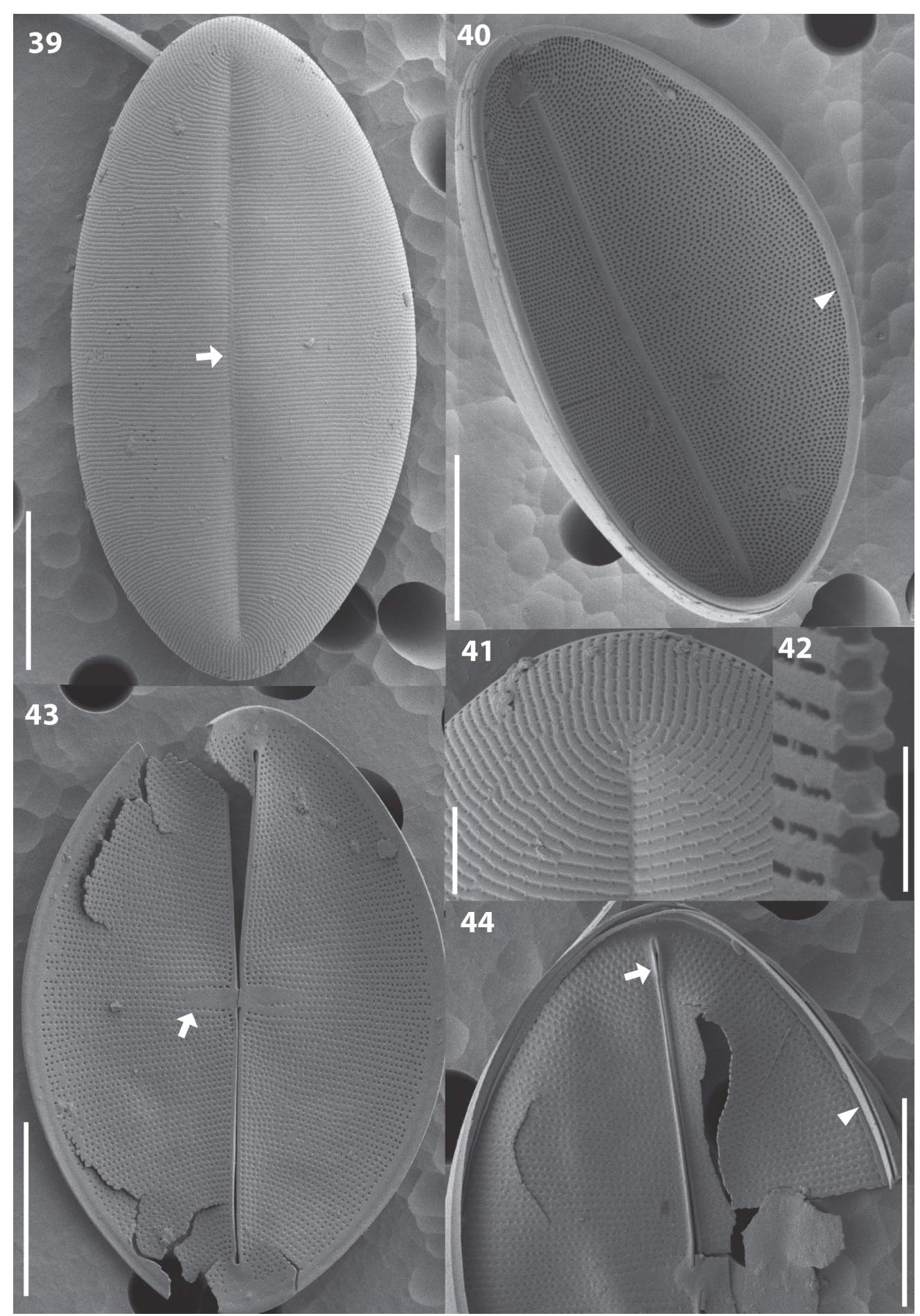

Figs 39-44. Cocconeis diaphana W.Sm. isolectotype SEM illustration. Mica labelled as "Cocconeis diaphana n.sp., Jersey, Aug. 14. 1852", deposited in the Van Heurck collection in Meise (BR). SV external view with a reduced central area (39, arrow) and striae composed of transversally elongated alveoli (39). SV internal view (40). Note the SV valvocopula (SVVC) with a smooth edge (40, arrowhead). Detail of the SV apex (41). Detail of a broken SV showing the double layered structure of the alveoli (42). RV external view with the central oblong-elongate central area reaching less than $1 / 3$ of the valve width (43, arrow). RV internal view with a low and straight helictoglossa (44, arrow) and the RV valvocopula $(\mathrm{RVVC})$ with a smooth edge (44, arrowhead). Scale bars $=10 \mu \mathrm{m}(39,40,43-44), 2 \mu \mathrm{m}(41), 1 \mu \mathrm{m}(42)$. 
The complete frustules appear obscure while the separate RV and SV appear translucent, which probably justifies W. Gregory's hesitation about the existence of a second taxon (C. diaphana W.Sm.) in his material. On the other hand the R.K. Greville drawing (Gregory 1857: fig. 25) probably superimposed the two valves. Contrarily to the latter drawing (Gregory 1857, fig. 25 reproduced in Fig. 4), the fascia does not reach the valve margin in the many specimens observed in this study.

The slide BM 1420 from Arran 56 (Gregory in Greville collection) is designated here as the lectotype, since nothing else has been traced that could be considered as original material studied by W. Gregory.

\section{Discussion}

\section{Ambiguities and synonymies}

The type of Cocconeis molesta has unique features and morphometrics (as discussed above) that cannot be confused with those of $C$. diaphana. Cocconeis molesta has small dimensions, a wide fascia, RV striae that are hardly discernible ( $c a .30$ in $10 \mu \mathrm{m}$ ), and helictoglossae close to the margin and bent in opposite directions.

Nevertheless, several recent papers refer to Cocconeis molesta as $C$. cf. molesta (e.g. Bruder \& Medlin 2007; Baldi et al. 2011) which shows the difficulty in accurately defining this taxon. Although Cocconeis molesta is rarely illustrated in publications, ambiguities have been noticed when analyzing some of the images: da Silva (1946, fig. 91) presents a drawing of a large RV fascia; an SV is seen in the LM (at http://www.diatomloir.eu/Site\%20Diatom/Sardiadeux.html), with a much bigger one corresponding to the RV; Majewska et al. (2014, pl. 2, fig. 13) showed the species in SEM with morphometrics (from fig. 13: ca. $57 \mu \mathrm{m}$ long, $30 \mu \mathrm{m}$ wide, with ca. 18 striae in $10 \mu \mathrm{m}$ ) but it might be Cocconeis diaphana var. diaphana.

On the other hand, the taxon Cocconeis molesta var. crucifera has been abundantly illustrated in both LM and SEM (e.g., Kobayasi \& Nagumo 1985; De Stefano et al. 2000; Sar et al. 2003) though the type material for this taxon has apparently not been checked nor compared with that of C. molesta.

Therefore, it is very likely that the images and illustrations in these references actually belong to Cocconeis molesta, with C. molesta var. crucifera being a synonym.

The specimens of Cocconeis diaphana from "Jersey, Pontac" (Figs 21-26) and from 'Sidmouth' (Figs 27-34) obviously pertain to two distinct taxa. Smith (1853) originally stated that there were two forms, but without indicating their respective origins. The present study shows that the specimens found in the "Jersey, Pontac" sample do fit the concept of Cocconeis diaphana var. diaphana (oblong shape, reduced RV transverse central area), while the specimens from "Sidmouth" (with a round to sub-orbicular shape and a wide fascia) belong to the unnamed variety $\beta$ which was later included as a synonym of $C$. dirupta by several authors (e.g., Cleve 1895; Hustedt 1931-1959). Cocconeis diaphana var. $\beta$ and $C$. dirupta have very similar features (Figs 27-38), except for the general shape of the valve illustrated in the original drawings, with $C$. diaphana var. $\beta$ being more elliptical. The conspicuous striae characterizing $C$. dirupta were not illustrated in the original drawing of $C$. diaphana var. $\beta$ (Fig. 2), but the two taxa may still be conspecific.

In the original drawings and descriptions of Cocconeis dirupta and C. diaphana var. $\beta$ there was no indication of a sigmoid raphe, which slightly contradicts our own observations on the original material of $C$. dirupta and $C$. diaphana var. $\beta$ (as discussed above).

Recently, Álvarez-Blanco \& Blanco (2014) proposed that C. dirupta and C. molesta var. crucifera are synonymous with $C$. diaphana, not by examining the type material, but based on the fact that the raphe 
is straight in all of the original illustrations of these taxa. However, after type examinations, Cocconeis dirupta has a slightly sigmoid raphe. Furthermore, Cocconeis dirupta, C. molesta and C. diaphana var. diaphana seem distinct taxa, while $C$. molesta var. crucifera is herein considered a synonym of C. molesta.

\begin{abstract}
Allied taxa
Some small Cocconeis species that have been recently described (Suzuki et al. 2001, 2008, 2012; Suzuki \& Tanaka 2006) from the Japanese coast, appear to share similarities with C. molesta and C. diaphana, particularly concerning their SV (on LM): e.g. C. churalis Hid.Suzuki, C. nagumoi Hid.Suzuki, C. shikinensis Hid.Suzuki and C. baikalensis (Skvortzov \& Meyer) Skvortzov. Nevertheless, these taxa have no fascia on their RV and possess several features which allows them to be easily differentiated in the SEM. Amongst the newly described taxa from Japan, Cocconeis tortilis Hid.Suzuki (Suzuki et al. 2014) has some morphological affinities with C. molesta, except for the RV fascia reaching the valve margin and the SV sternum being larger than in C. molesta. The spiral aspect of Cocconeis tortilis may be due to the ecology of the taxon (found as an epiphyte on Codium intricatum Okamura). Suzuki et al. (2014: 223) also stated that Cocconeis molesta var. crucifera (synonym of C. molesta) has no stauros, but a wide fascia.
\end{abstract}

\title{
Conclusions
}

Our study stresses the importance of checking all possible original materials (especially types) in order to make an improved species definition. Thus, the name Cocconeis molesta var. crucifera Grunow ex Cleve could have been avoided. However, H. Van Heurck (1896), by examining Kützing's original material showed that there were no differences between the type of Cocconeis molesta and A. Grunow's variety. Our observations of these type materials corroborated H. Van Heurck's supposition that C. molesta var. crucifera is a synonym of $C$. molesta var. molesta. [Incidentally, it should be noted that C. molesta var. crucifera Grunow was not validly published in 1880, since it was not accompanied by a description or an illustration, but only by the mere mention of included subordinate taxa: cf. McNeill et al. (2012), art. 36.1(d); only f. major Grunow and f. minor Van Heurck were illustrated and thus valid. The first valid publication of var. crucifera is probably by Cleve (1895: 175). The same situation occurs for C. amygdalina (in Van Heurck 1880-1885) since only f. minor Van Heurck and f. major Grunow were illustrated; the first valid publication of the epithet amygdalina is also by Cleve (1895)].

Similarly, our examination of the original material of Cocconeis diaphana W.Sm. allowed us to point out the differences between the two syntypes, which indeed belong to different taxa. Lectotypes have been designated here for $C$. diaphana and $C$. dirupta.

From this study, three species have been recognized: Cocconeis molesta Kütz., C. diaphana W.Sm. and $C$. dirupta W.Greg. Cocconeis diaphana var. $\beta$ is considered to be a synonym of $C$. dirupta and C. molesta var. crucifera a synonym of C. molesta var. molesta.

\section{Acknowledgments}

We wish to pay tribute to our co-author Pierre Compère who was an excellent taxonomist and enthusiastic collaborator with a great knowledge, particularly on the rules of botanical nomenclature. We acknowledge Bart Van de Vijver (Botanic Garden Meise, Meise, Belgium) for allowing us to use the Van Heurck slide collection facilities and for providing SEM photographs of the original material of Cocconeis diaphana, Friedel Hinz (AWI, Bremerhaven, Germany) for her bibliographic help and Peter Esteve (USR 3278, CRIOBE, Perpignan, France) for his help about iconography. Two anonymous reviewers are greatly acknowledged for their constructive remarks. The Labex CORAIL, USR 3278 
(CNRS-EPHE, CRIOBE) is acknowledged for funding the CORDIA program (COral Reef DIAtoms) in the South Pacific.

\section{References}

Álvarez-Blanco I. \& Blanco S. 2014. Benthic diatoms from Mediterranean coasts. Bibliotheca Diatomologica 60, Schweizerbart Science Publishers, Stuttgart.

Anonymous 1975. Proposal for a standardization of diatom terminology and diagnoses. Beihefte zur Nova Hedwigia 53: 323-354.

Baldi F., Facca C., Marchetto D., Nguyen T.N.M. \& Spurio R. 2011. Diatom quantification and their distribution with salinity brines in coastal sediments of Terra Nova Bay (Antarctica). Marine environmental Research 71: 304-311. http://dx.doi.org/10.1016/j.marenvres.2011.02.005

Bruder K. \& Medlin L.K. 2007. Molecular assessment of phylogenetic relationships in selected species/ genera in the naviculoid diatoms (Bacillariophyta). I. The genus Placoneis. Nova Hedwigia 85: 331352. http://dx.doi.org/10.1127/0029-5035/2007/0085-0331

Cleve P.T. 1895. Synopsis of the naviculoid diatoms. Kongliga Svenska Vetenskaps-Akademiens Handlingar 27 (3): 1-219. http://dx.doi.org/10.5962/bhl.title.54740

De Stefano M., Marino D. \& Mazzella L. 2000. Marine taxa of Cocconeis on leaves of Posidonia oceanica, including a new species and two new varieties. European Journal of Phycology 35: 225-242. http://dx.doi.org/10.1080/09670260010001735831

Ehrenberg C.G. 1837 [1836]. Zusätze zur Erkenntniss grosser organischer Ausbildung in den kleinsten thierischen Organismen. Abhandlungen der Königlichen Akademie der Wissenschaften zu Berlin 1835: $151-180$.

Foged N. 1978. Diatoms in Eastern Australia. Bibliotheca Phycologica 41, Schweizerbart Science Publishers, Stuttgart.

Gregory W. 1857. On new forms of marine Diatomaceae, found in the Firth of Clyde and in Loch Fyne, illustrated by numerous figures drawn by R.K. Greville, L.L.D., F.R.S.E. Transactions of the Royal Society of Edinburgh 21: 473-542.

Hustedt F. 1931-1959. Die Kieselalgen Deutschlands, Österreichs und der Schweiz unter Berücksichtigung der übrigen Länder Europas sowie der angrenzenden Meeresgebiete. In: Rabenhorst L. (ed.) 2. Teil. - Kryptogamen-Flora von Deutschland, Österreich und der Schweiz. Band 7, Teil 2. Akademische Verlagsesellschaft, Leipzig.

Jahn R., Kusber W.-H. \& Romero O.E. 2009. Cocconeis pediculus Ehrenberg and C. placentula Ehrenberg var. placentula (Bacillariophyta): Typification and taxonomy. Fottea 9: 275-288. http:// dx.doi.org/10.5507/fot.2009.027

Kobayasi H. \& Nagumo T. 1985. Observations on the valve structure of marine species of the diatom genus Cocconeis Ehr. Hydrobiologia 127: 97-103. http://dx.doi.org/10.1007/BF00004189

Kützing F.T. 1844. Die Kieselschaligen Bacillarien oder Diatomeen. Nordhausen. http://dx.doi. org/10.5962/bhl.title.64360

Lobban C.S., Schefter M., Jordan R.W., Arai Y., Sasaki A., Theriot E.C., Ashworth M., Ruck E.C. \& Pennesi C. 2012. Coral-reef diatoms (Bacillariophyta) from Guam: new records and preliminary checklist, with emphasis on epiphytic species from farmer-fish territories. Micronesica 43: 237-479. 
Majewska R., D’Alelio D. \& De Stefano M. 2014. Cocconeis Ehrenberg (Bacillariophyta), a genus dominating diatom communities associated with Posidonia oceanica Delile (monocotyledons) in the Mediterranean Sea. Aquatic Botany 112: 48-56. http://dx.doi.org/10.1016/j.aquabot.2013.07.008

McNeill J., Barrie F.R., Buck W.R., Demoulin V., Greuter W., Hawksworth D.L., Herendeen P.S., Knapp S., Marhold K., Prado J., Prud'homme van Reine W.F., Smith G.F., Wiersema J.H. \& Turland N. (eds \& Comps) 2012. International Code of Nomenclature for algae, fungi, and plants (Melbourne Code). Regnum Vegetabile 154: 1-208.

Medlin L. \& Kaczmarska I. 2004. Evolution of the diatoms: V. Morphological and cytological support for the major clades and a taxonomic revision. Phycologia 43 (3): 245-270. http://dx.doi.org/10.2216/ i0031-8884-43-3-245.1

Rabenhorst L. 1864. Flora Europaea Algarum aquae dulcis et submarinae. Sectio I. Algas diatomaceas complectens, cum figuris generum omnium xylographice impressis. Eduard Kummer, Leipzig. http:// dx.doi.org/10.5962/bhl.title.7029

Riaux-Gobin C. \& Compère P. 2008. New Cocconeis taxa from coral sands off Réunion Island (Western Indian Ocean). Diatom Research 23: 129-146. http://dx.doi.org/10.1080/0269249X.2008.9705742

Riaux-Gobin C., Romero O., Compère P. \& Al-Handal A.Y. 2011. Small-sized Achnanthales (Bacillariophyta) from coral sands off Mascarenes (Western Indian Ocean). Bibliotheca Diatomologica 57: 1-234.

Riaux-Gobin C., Romero O., Coste M. \& Galzin R. 2013. A new Cocconeis (Bacillariophyceae) from Moorea Island, Society Archipelago, South Pacific Ocean, with distinctive valvocopula morphology and linking system. Botanica Marina 56: 339-356. http://dx.doi.org/10.1515/bot-2012-0162

Riaux-Gobin C., Compère P., Coste M., Straub F. \& Taxboek L. 2014a. Cocconeis napukensis sp. nov. (Bacillariophyceaea) from Napuka Atoll (South Pacific) and lectotypification of Cocconeis subtilissima Meister. Fottea 14 (2): 209-224. http://dx.doi.org/10.5507/fot.2014.016

Riaux-Gobin C., Compère P., Romero O.E. \& Williams D.M. 2014b. Cocconeis pinnata W. Gregory ex Greville (Bacillariophyta): Lectotypification and an emended description after examination of type material and South Pacific specimens. Phytotaxa 156: 81-99. http://dx.doi.org/10.11646/ phytotaxa.156.3.1

Romero O.E. 2011. Morphological study of the genus Cocconeis Ehrenberg (Bacillariophyceae) collected during the 1897-1899 Belgian Antarctic Expedition. Botanica Marina 54: 179-188. http:// dx.doi.org/10.1515/bot.2011.020

Romero O.E. \& Riaux-Gobin C. 2014. Two closely-related species of Cocconeis (Bacillariophyta): comparative study and typification. Plant Ecology and Evolution 147 (3): 426-438. http://dx.doi. org/10.5091/plecevo.2014.996

Ross R., Cox E.J., Karayeva N.I., Mann D.G., Paddock T.B.B., Simonsen R. \& Sims P.A. 1979. An amended terminology for the siliceous components of the diatom cell. Beihefte zur Nova Hedwigia 64: 513-533.

Round F.E., Crawford R.M. \& Mann D.G. 1990. The Diatoms: Biology and morphology of the genera. Cambridge University Press, Cambridge.

Sar E.A., Romero O.E. \& Sunesen I. 2003. Cocconeis Ehrenberg and Psammococconeis Garcia (Bacillariophyta) from the Gulf of San Matías, Patagonia, Argentina. Diatom Research 18: 79-106. http://dx.doi.org/10.1080/0269249X.2003.9705575

Silva A.A. da 1946. Diatomáceas fósseis de Portugal: (Jazigos de Rio. Maior, Obidos e Al. piarça). Boletim da Sociedade Geologica de Portugal 6 (1-2): 1-168. 
Smith W. 1853. A synopsis of the British Diatomacea: with remarks on their structure, functions and distribution; and instructions for collecting and preserving specimens. Vol. 1. J. Van Voorst, London. http://dx.doi.org/10.5962/bhl.title.10706

Suzuki H., Nagumo T. \& Tanaka J. 2001. A new marine diatom, Cocconeis shikinensis sp. nov. (Bacillariophyceae) from Japan. Phycological Research 49: 137-144. http://dx.doi.org/10.1046/j.1440$\underline{1835.2001 .00234 . \mathrm{x}}$

Suzuki H. \& Tanaka J. 2006. A new marine diatom Cocconeis nagumoi Hid.Suzuki (Bacillariophyceae) from Japan. The Journal of Japanese Botany 81: 282-288.

Suzuki H., Tanaka J., Nagumo T. \& Kuzima A.E. 2008. Morphological and taxonomical study of Cocconeis baikalensis (Skvortzov \& Meyer) Skvortzov. Nineteenth International Diatom Symposium 2006. Listvyanka, Russia (Y. Likhoshway, ed.): 107-114.

Suzuki H., Nagumo T. \& Tanaka J. 2012. Cocconeis churalis: a new marine diatom (Bacillariophyta, Cocconeidaceae) from Japan. Phytotaxa 68: 36-44. http://dx.doi.org/10.11646/phytotaxa.68.1.4

Suzuki H., Nagumo T. \& Tanaka J. 2014. Cocconeis tortilis: a new marine diatom (Bacillariophyta, Cocconeidaceae) from Japan. Phytotaxa 161: 219-226. http://dx.doi.org/10.11646/phytotaxa.161.3.5

Van Heurck H. 1880-1885. Synopsis des Diatomées de Belgique. Published by author, Antwerp.

Van Heurck H. 1896. A treatise on the Diatomaceae. Translated by E. Baxter, William Wesley \& Son, London. http://dx.doi.org/10.5962/bhl.title.2002

Manuscript received: 22 August 2015

Manuscript accepted: 4 February 2016

Published on: 14 June 2016

Topic editor: Koen Martens

Desk editor: Natacha Beau

Printed versions of all papers are also deposited in the libraries of the institutes that are members of the EJT consortium: Muséum national d'Histoire naturelle, Paris, France; Botanic Garden Meise, Belgium; Royal Museum for Central Africa, Tervuren, Belgium; Natural History Museum, London, United Kingdom; Royal Belgian Institute of Natural Sciences, Brussels, Belgium; Natural History Museum of Denmark, Copenhagen, Denmark. 